\title{
Transcription-mediated Amplification
}

National Cancer Institute

\section{Source}

National Cancer Institute. Transcription-mediated Amplification. NCI Thesaurus. Code C122175.

A technique used to selectively replicate nucleic acid sequences from RNA templates using reverse transcriptase and RNA polymerase. Reverse transcriptase generates CDNA from the region of interest using primers and then RNA polymerase generates copies of the orig inal RNA template. 